\title{
Business cycles and the role of confidence: Evidence from Europe
}

\author{
Bob M cN abb and KarlT aylor ${ }^{2}$
}

${ }^{1}$ Economics section, Cardiff Business School, Aberconway Building, Colum Drive, Cardiff. CF10 3EU

${ }^{2}$ Department of Economics, University of Leicester, University Road, Leicester. LE1 7RH

Abstract: Using an under-utilised dataset on consumer and business confidence indicators across the UK, France, Italy and the Netherlands, this paper considers the extent to which such indicators are linked to GDP and the business cycle. We adopt, cross correlation descriptive statistics, Granger causality tests, variance decomposition, and forecast probit tests to investigate the properties of the data. In general consumer and business confidence indicators are leading indicators and pro-cyclical. There is some evidence of causality between the indicators and GDP and confidence indicators would appear to have good predictive power of cycle turning points in relation to other leading indicators. 


\section{Introduction}

The aim of this paper is to provide an investigation and a comprehensive empirical analysis into whether confidence indicators can be used to predict business cycle activity across four European economies. The motivation for doing this is to firstly employ a data set which as far as we are aware has to date been underused; and secondly, to see if consumer or business confidence indicators provide any evidence over and above existing leading indicators. Section II provides a brief summary of the literature relating confidence indices to output trends, section III describes the data. The empirical analysis takes place in sections IV, V, VI and VII, which consider cross sectional properties of the data, causality, variance decomposition and forecasts respectively. Section VIII concludes.

\section{Existing literature}

A number of papers exist in the literature, both theoretical and applied, which investigate the effect of confidence upon economic activity. Of the former Yew-Kuang (1992) asks whether a collapse in business confidence could trigger a recession. For instance, a stock market crash may induce a depression by reducing business confidence and aggregate demand. Potter (1999) suggests that business cycle asymmetries found in post war US data are inconsistent with the trends of the economy during the Great Depression. In a model of rational expectations such inconsistencies are examined by focusing upon the confidence of investors.

Considering the empirical literature on the impact of confidence upon economic activity, Matsusaka and Sbordone (1995) examining trends in US output over the period 1953 to 1988 find that consumer sentiment Granger causes GNP fluctuations, even after controlling for other potential leading indicators. Furthermore, variance decompositions 
imply that between $13-16 \%$ of GNP variation is explained by consumer sentiment. Carroll $\notin$ al (1994) forecasting household expenditure, find that lagged consumer sentiment does have a degree of explanatory power in predicting current changes in household spending. The inability of economic forecasters to predict the 1991 US recession led Batchelor and Dua (1998) to investigate the role of consumer confidence indices. Their results show that consumer confidence would have improved the forecasts of the 1991 US downturn, but used at other times may have been misleading.

Eppright $\notin a l$ (1998) use multivariate VAR analysis on US data to investigate whether indices of aggregate consumer attitude and expectations possess any information not contained in other economic indicators. Their analysis reveals that consumer expectation measures provide predictive power over and above other leading indicators. Acemoglu and Scott (1994) reject the rational expectations permanent income hypothesis for the UK due to the strong predictive power of consumer confidence, and not labour income or any other macro variable. Bodo $\notin a l$ (2000) find that business confidence indices perform the best in terms of forecasting capability in the euro area using ARIMA and cointegrated VAR techniques. Lee and Shields (2000) examining UK manufacturing output trends over the period 1975 to 1993 also finds a role for business confidence in explaining the time profile of industrial outputs.

The literature relating confidence to output fluctuation is small and largely related to US evidence. After introducing the data in the following section we analyse the extent to which confidence indicators can be used as leading indicators across four countries. 


\section{Data}

The data used in the empirical analysis looks at four countries - the UK, France, Italy and the Netherlands over the period 1983 to 1998 based upon quarterly data. We gain measures of consumer and business confidence from detailed monthly reports called the Eurqpern Economy Consmer Surrey Results and Business and Consmer Surrey Results respectively ${ }^{1}$. The indicator is a weighted average of the percentage responses to a range of questions $^{2}$ and is constructed so the indicator lies within the range -100 to +100 , where positive values indicate optimism. We add 100 to this index to enable us to convert the data to logarithms, i.e. all the data takes on positive values. The consumer and business confidence data are shown in Figures 1 to 4 for each country.

$$
<<\text { FIGURES } 1 \text { to } 4 \text { HERE }>>
$$

Abel $\notin a l$ (1998) note that historically the consumer confidence indicator has been sensitive to output trends. For example, in the UK both consumer and business confidence indicators dropped significantly during periods of recession - notably the 1990 UK trough. In addition to the confidence indicators other potential leading indicators employed are: the real wage, employment, consumer expenditure, government expenditure, gross fixed investment, money supply (both broad and narrow measures), unemployment rate, interest rate, and the real effective exchange rate. These data are available for each country from Datastream.

\footnotetext{
${ }^{1}$ Note that although the confidence indicators are available on a monthly basis, we aggregate to a quarterly interval. The reason that we do this is that GDP is only available on a quarterly basis. Although others have used industrial production, which is available by month, to proxy economic activity e.g. Andreou etal.(2000) it is debatable whether or not this is a good indicator. For example in 1995 industrial production accounted for only 26.6\% of UK GDP. Moreover Andreou $\in a l$. $(2000)$ note that industrial production is twice as volatile as quarterly GDP in the UK. Consequently, conclusions may differ from studies based upon industrial production data in comparison to those that use GDP. Furthermore, the business and consumer confidence indicators cover sectors other than manufacturing.

${ }^{2}$ The appendix shows the questions used in both the consumer and business confidence surveys.
} 
The next section considers the cross sectional properties of the data and identifies potential leading indicators across countries.

\section{Cross sectional properties}

We employ cross correlation coefficients to establish whether the variables are leading or lagging indictors, and counter-cyclical or pro-cyclical, as is common in the literature (Blackburn and Ravn, 1992; Millard eal, 1997; Andreou eal, 2000). Initially, all the data are detrended subject to the Hodrick-Precott filter ${ }^{3}$. After all the data has been detrended using the HP filter we consider co-movements in variables to that of GDP. Entries in column t(through Tables 1 to 4 ) are the contemporaneous cross correlation coefficients between each explanatory variable and GDP, and the entries in columns $t-1$ and $t+1(i=1,2,3,4)$ are the non-contemporaneous cross correlations with GDP. A positive (negative) coefficient indicates that a series is pro-cyclical (counter-cyclical), and a number close to zero indicates that the series is largely unrelated to the GDP cycle. A relatively large number in the column $t i(t+1)$ shows that the series tends to lead (lag) the GDP cycle by iquarters.

The results are given in Tables 1 to 4 for the UK, France, Italy and the Netherlands respectively, over the period 1983q1 to 1998q4. In the UK and France (Tables 1 and 2)

$$
<<\text { TABLES } 1 \text { to } 4 \text { HERE }>>
$$

\footnotetext{
${ }^{3}$ The Hodrick Prescott (HP) filter (1980) can be used to define the cyclical component of a series, $y_{t}^{C}=y_{t}-y_{t}^{H P}$, where $y_{t}$ denotes the series in question and $y_{t}^{H P}$ is the estimate of the trend from the HP filter. Given that $\tau_{t}$ is the trend of the series $Y_{t}$ the trend component is obtained by solving the following convex minimisation problem: $\underset{\left\{\tau_{t}\right\}_{t=1}^{\mathbb{N}}}{\mathbb{M}} \sum_{t=1}^{T}\left(y_{t}-\tau_{t}\right)^{2}+\lambda \sum_{t-2}^{T-1}\left[\left(\tau_{t+1}-\tau_{t}\right)-\left(\tau_{t}-\tau_{t-1}\right)\right]^{2}$ where $\lambda$ is a smoothing parameter. In this paper we define the value as $\lambda=1600$ which is common practice for quarterly data.
} 
the three strongest leading indicators, which are also pro-cyclical, are employment, money supply M3 and business confidence. In Italy both consumer expenditure and gross fixed investment display traits of leading and lagging the cycle, the latter being counter-cyclical. Business confidence clearly leads the cycle, whilst the real wage and unemployment lag. Consumer expenditure, unemployment and business confidence are all leading indicator in the Netherlands. A common finding across each country is that both consumer and business confidence are pro-cyclical and can be considered as leading indicators, with business confidence often one of the strongest three correlation's at fixed $t$

Next we use multivariate analysis to consider which series is most strongly correlated with GDP, controlling for country and time effects, by pooling across countries and time as follows:

$$
\mathrm{GDP}_{\mathrm{ct}}=\beta+\varphi \mathrm{Tim} \mathrm{e}_{\mathrm{t}}+\delta \mathrm{C} \text { ountry } y_{\mathrm{c}}+y_{\mathrm{ct}} \theta+v_{\mathrm{ct}}
$$

where GDP is detrended using the HP filter, and the matrix $y$ contains the potential leading indicators also detrended by the HP method. The results of this analysis are shown in Table 5. Clearly, the business confidence indicator is significant and stands out

$$
<<\text { TABLE } 5 \text { HERE }>>
$$

as the third largest coefficient (column 1), whilst consumer and government expenditure exhibit the strongest effects. Removing, consumer and government expenditure (column 2) also provides a role for consumer confidence, although the negative coefficient suggests that on average across time and countries it lags the cycle. The following section looks at any causality links between the potential leading indicators and the cycle. 


\section{Causality}

We carry out tests to see whether the coefficients of a subset of jointly determined variables in a VAR are equal to zero. Included in the VAR are GDP, the leading indicators identified from the cross correlation's (see Tables 1 to 4) plus the consumer and business confidence indicators. Thus the test is based upon the following:

$$
\mathrm{GDP}_{\mathrm{t}}=\alpha+\sum_{\mathrm{p}=1}^{\mathrm{L}} \sum_{\mathrm{i}=1}^{\mathrm{M}} \Omega_{\mathrm{pi}} \text { Lead }_{\mathrm{pt}-\mathrm{i}}+\sum_{\mathrm{i}=1}^{\mathrm{M}} \Phi_{\mathrm{i}} \mathrm{C} \text { onsum er }_{\mathrm{t}-\mathrm{i}}+\sum_{\mathrm{i}=1}^{\mathrm{M}} \Theta_{\mathrm{i}} \text { Bu siness }_{\mathrm{t}-\mathrm{i}}+\kappa_{\mathrm{t}}
$$

A test of non-causality amounts to a null hypothesis of: $\Phi_{i}=0$ for consumer confidence not Granger causing GDP, $\Theta_{i}=0$ for business confidence not Granger causing GDP, and a joint test of consumer and business confidence not causing GDP of $\Phi_{i}+\Theta_{i}=0$. If the null hypothesis is rejected this signifies that confidence indicators Granger cause GDP. Note all data is first differenced as ADF tests for stationarity revealed the data to be I(1). The results are shown in Table 6 for each of the four countries. For the UK the

$$
<<\text { TABLE } 6 \text { HERE }>>
$$

evidence suggests that consumer confidence does Granger cause the GDP cycle, whilst GDP Granger causes business confidence. In France and Italy the hypothesis that business confidence does not Granger cause the cycle can be rejected. Only in the Netherlands are no causality links between confidence and the GDP cycle established. The following considers the proportion of forecast errors explained by confidence indicators in relation to other indicators of economic activity.

\section{Variance decomposition}

An alternative way to assess the quantitative importance of confidence indicators and other leading indicators in GDP fluctuations is to use the VAR residuals to decompose the innovations of each variable, Sims (1980a, 1980b). Defining u as a vector of forecast 
errors from a trivariate VAR and $\Sigma$ as the corresponding covariance matrix, then it is possible to find an orthonormal vector $\mathrm{V}$ and a lower triangular matrix $\mathrm{G}$ such that $\mathrm{GG}^{\prime}=\Sigma$ and $\mathrm{Gv}=\mathrm{u}$ Since $\mathrm{v}$ is orthonormal and $\mathrm{G}$ is lower triangular it is possible to derive the percentage contributions of innovations from each of the forecast errors associated with each endogenous variable. This can be applied to any arbitrary length forecast. We apply this method to the decompositions of GDP and the leading indicators from one to eight quarters ahead, with the results shown in Tables 7 to 10 . In general

$$
<<\text { TABLES } 7 \text { to } 10 \text { HERE }>>
$$

both consumer and business confidence indicators are able to explain relatively large percentages of the $\mathrm{k}$-ahead forecasts variance of GDP. In the UK, Table 7, for first quarter variance decompositions consumer confidence explains 8.6\% of GDP variance, rising to $20.2 \%$ by 3 quarters ahead. Over each forecast horizon consumer confidence explains a larger proportion of UK GDP variance than business confidence. This is also true for Italy, Table 9, although both confidence indices explain a higher percentage than in the UK. Business confidence has a large role to play in both France (Table 8) and the Netherlands (Table 10), dominating the proportion explained by consumer confidence. Tables 7 to 10 reveal that either consumer or business confidence dominate the other potential leading indicators ${ }^{4}$. The following section considers whether the confidence indicators can be employed to predict turning points in the cycle.

\section{Forecasts}

In order to gain an insight into the predictive power of consumer and business confidence, both of which are potential leading indicators (see above), a probit model is

\footnotetext{
${ }^{4}$ Although changing the ordering the variables entered in the VAR affected the percentage contributions, the overall effects remained unchanged in that confidence indicators explained the largest proportion of GDP forecast variance.
} 
used, with all data detrended by the HPF, following Estrella and Mishkin (1998). The probit form is defined by the following relationship:

$$
\mathrm{S}_{\mathrm{t}+\mathrm{k}}^{*}=\mathrm{x}_{\mathrm{t}} \beta+\varepsilon_{\mathrm{t}}
$$

where $S_{t+k}^{*}$ is an unobservable, which determines the occurrence of a recession at time $t$ where $\mathrm{k}$ is the length of the forecast horizon. The error term $\varepsilon_{\mathrm{t}}$ is normally distributed, $\mathrm{x}_{t}$ is a matrix of independent variables (all detrended by the HPF, see above) including a constant with a corresponding vector of coefficients $\beta$. The observable recession indicator $r_{\tau}$ is related to the above model by:

$$
r_{t}=\left\{\begin{array}{l}
1, \text { if } s_{t}^{*}>0 \\
0, \text { otherw ise }
\end{array}\right.
$$

The form of the estimating equation is:

$$
\mathrm{P}\left(r_{\mathrm{t}+\mathrm{k}}=1\right)=\mathrm{F}\left(\mathrm{x}_{\mathrm{t}} \beta\right)
$$

where $\mathrm{F}$ is the cumulative normal distribution function corresponding to $\varepsilon$. The model is estimated by maximum likelihood, with the likelihood function defined as follows:

$$
\mathrm{L}=\prod_{\left[\mathrm{r}_{+\mathrm{k}}=1\right]} \mathrm{F}\left(\mathrm{x}_{\mathrm{f}} \beta\right) \prod_{\left[\mathrm{r}_{\mathrm{t}+\mathrm{k}}=0\right]}\left[1-\mathrm{F}\left(\mathrm{x}_{\mathrm{t}} \beta\right)\right]
$$

We define a recession when filtered GDP is below trend. In practice the forecast horizon is four quarters ahead, so $\mathrm{k}$ is between 1 and 4 . The principle measure of the models explanatory power is a pseudo $\mathrm{R}^{2}$ developed by Estrella (1998):

$$
\text { pseudo } R^{2}=1-\left(\frac{\log L_{u}}{\log L_{c}}\right)^{-(2 / n) \log L_{c}}
$$

where $L_{c}, L_{u}$ is the maximum value of the likelihood under the constraint that all coefficients except the intercept are zero and the unconstrained maximum value of the likelihood respectively. 
For hypothesis testing after predicting two or more quarters ahead standard t-ratios cannot be used. This is because an overlapping data problem occurs in that the forecast horizon is longer than the observation interval. Consequently, forecast errors are likely to be serially correlated. As a result t-statistics are calculated using standard errors adjusted for the overlapping data problem by adopting the Newey-West (1987) approach to serially correlated errors. An estimator of the covariance matrix is given by:

$$
\mathrm{Q}=\frac{1}{\mathrm{n}} \sum_{\mathrm{i}=1}^{\mathrm{n}} \mathrm{e}_{\mathrm{i}}^{2} \mathrm{x}_{\mathrm{i}} \mathrm{x}_{\mathrm{i}}^{\prime}+\frac{1}{\mathrm{n}} \sum_{\mathrm{z}=1}^{\mathrm{M}} \sum_{\mathrm{t}=\mathrm{z}+1}^{\mathrm{n}} \omega_{\mathrm{k}} e_{t} e_{t-z}\left(\mathrm{x}_{\mathrm{k}} \mathrm{x}_{t-z}^{\prime}+\mathrm{x}_{\mathrm{t}-\mathrm{z}} \mathrm{x}_{t}^{\prime}\right)
$$

where $\omega_{\mathrm{k}}=\mathrm{z} \div(\mathrm{M}+1)$ which is a weighting coefficient with $\mathrm{M}$ being predetermined, $\mathrm{x}$ is a matrix of dependent variables and $e$ is a vector of residuals.

The results are shown in Tables 11 to 14 for the UK, France, Italy and the Netherlands respectively. The t-statistics show that the majority of the potential leading indicators are

$$
<<\text { TABLES } 11 \text { to } 14 \text { HERE }>>
$$

significant. In the UK both business and consumer confidence can be used to predict the cycle. However, the predictive power of the business confidence indicator tails off after 1 period ahead forecasts, where it has the largest coefficient, to being ranked $4^{\text {th }}$ when predicting 4 periods ahead. For the UK although the confidence indicators are always in the group of largest four coefficients, employment has the greatest predictive capability across forecast horizons.

In France (Table 12) business confidence has the largest predictive capability in 1 and 2 period ahead forecasts, falling to $3^{\text {rd }}$ largest coefficient thereafter. Although consumer confidence has no predictive power in 1 and 2 period ahead forecasts it is ranked the second largest impact thereafter. Confidence indicators have no predictive power in Italy, never one of the four largest coefficients, and are often insignificant. Government 
expenditure seems to do the best job of predicting turning points in the Italian economy. Turing to the Netherlands (Table 14) across each forecast horizon business confidence has the most predictive power out of the potential leading indicators, followed by consumer expenditure. In most $\mathrm{k}$ ahead periods consumer confidence also has significant predictive power ranked either $3^{\text {rd }}$ or $4^{\text {th }}$ out of the potential leading indicators.

\section{Conclusions}

This paper has introduced a dataset containing business and consumer confidence indicators to explore to what extent such variables are related to the GDP cycle. Investigation of the confidence properties over four European countries from 1983 to 1998 suggests that in general they are leading indicators, pro-cyclical, have the potential to Granger cause GDP, explain a large percentage of the variance of GDP decompositions, and perhaps most strikingly have good predictive power of turning points in the cycle in the face of controlling for other potential leading indicators. 


\section{$\underline{\text { H arm onized consum er survey }}$}

The consumer confidence indicator is the arithmetic average of results to the following five questions:-

Q1 How does the financial situation of your household now compare with what it was 12 months ago?
i. got a lot better
ii. got a little better
iii. stayed the same
iv. got a little worse
v. don't know

Q2 How do you think the financial position of your household will change over the next 12 months?
i. get a lot better
ii. get a little better
iii. stay the same
iv. get a little worse
v. don't know

Q3 How do you think the general economic situation in this country has changed over the last 12 months?
i. $\quad$ got a lot better
ii. got a little better
iii. stayed the same
iv. got a little worse
v. don't know

Q4 How do you think the general economic situation in this country will develop over the next 12 months?
i. get a lot better
ii. get a little better
iii. stay the same
iv. get a little worse
v. don't know

Q5 Over the next 12 months, how do you think the amount of money you will spend on major purchases will compare with what you spent over the last 12 months? Will it be:
i. much more?
ii. a little more?
iii. about the same?
iv. a little less?
v. much less?
vi. don't know 


\section{H arm onized business survey}

The business confidence indicator is the arithmetic average of results to the following five questions:-

Q1 Production trend observed in recent months

i. up

ii. unchanged

iii. down

Q2 Assessment of order book-levels

i. above normal

ii. normal

iii. below normal

Q3 Assessment of export order-book levels

i. above normal

ii. normal

iii. below normal

Q4 Assessment of stocks of finished products
i. above normal
ii. normal
iii. below normal

Q5 Production expectations for the months ahead

i. up

ii. unchanged

iii. down 


\section{R eferences}

Abel, A., Bernanke, B. and McNabb, R. (1998) M acroeconon ics: Eurqpean E dittion AddisonWesley.

Acemoglu, D. and Scott, A. (1994) 'Consumer confidence and rational expectations: Are agents beliefs consistent with economic theory?', E conomicjaurnal 104(422), pp.119.

Andreou, E., Osborn, D. and Sensier, M. .(2000) 'A comparison of the statistical properties of financial variables in the USA, UK and Germany over the business cycle', TheM andhetersdnool, 68(4), pp.396-418.

Batchelor, R. and Dua, P. (1998) 'Improving macro-economic forecasts: The role of consumer confidence', Intemationaluaurnal of F oreeasting 14(1), pp.71-81

Blackburn, K. and Ravn, M. (1992) 'Business cycles in the United Kingdom: facts and fictions', Econonice, 59(236), pp.383-401.

Bodo, G., Golinelli, R. and Parigi, G. (2000) 'Forecasting industrial production in the euro area', Empirical E conom ics 25(4), pp.541-61.

Carroll, C., Fuhrer, J. and Wilcox, D. (1994) 'Does consumer sentiment forecast household spending? If so, why?', A merian E conom icReriev, 84(5), pp.1397-1408.

Eppright, D., Arguea, N. and Huth, W. (1998) 'Aggregate consumer expectation indexes as indicators of future consumer expectations', Jamal ofE conom icPsychology, 19(2), pp.215-35.

Estrella, A. (1998) 'A new measure of fit for equations with dichotomous dependent variables', JaunalofBusinesand E conom icStatistics 16(7), pp.198-205.

Estrella, A. and Mishkin, F. (1998) 'Predicting US recessions: Financial variables as leading indicators', Reviev ofE conom icsand Statistics 80(1), pp.45-61. 
Hodrick, R. and Prescott, E. (1980) 'Post-war US business cycles: An empirical investigation', Carnegie Mellon University, manuscript.

Lee, K. and Shields, K. (2000) 'Expectations formation and business cycle fluctuations: An empirical analysis of actual and expected output in UK manufacturing, 19751996', Oxford Bulletin ofE conomicsand Statistics 62(4), pp.463-90.

Matsusaka, J. and Sbordone, A. (1995) 'Consumer confidence and economic fluctuations', E conom ic Inquiry, 33(2), pp.296-318.

Millard, S., Scott, A. and Sensier, M. (1997) 'The labour market over the business cycle: Can theory fit the facts?', Oxford Revier ofE conom icPolidy, 13(3), pp.70-92.

Newey, W. and West, K. (1987) 'A simple positive semi-definite heteroskedasticity and autocorrelation consistent covariance matrix', E conometrica, 55(3), 703-8.

Potter, S. (1999) 'Fluctuations in confidence and asymmetric business cycles', Domestic Research Function, Federal Reserve Bank of New York.

Sims, C. (1980a) 'Macroeconomics and reality', E conometrica, 48(1), pp.1-48.

Sims, C. (1980b) 'Comparison of interwar and postwar business cycles: Monetarism reconsidered', A merian E conom icReviev, 70(2), pp.250-57.

Yew-Kuang, N. (1992) 'Business confidence and depression prevention: A mesoeconomic perspective', A merian E conom icReviev, 82(2), pp.379-85. 


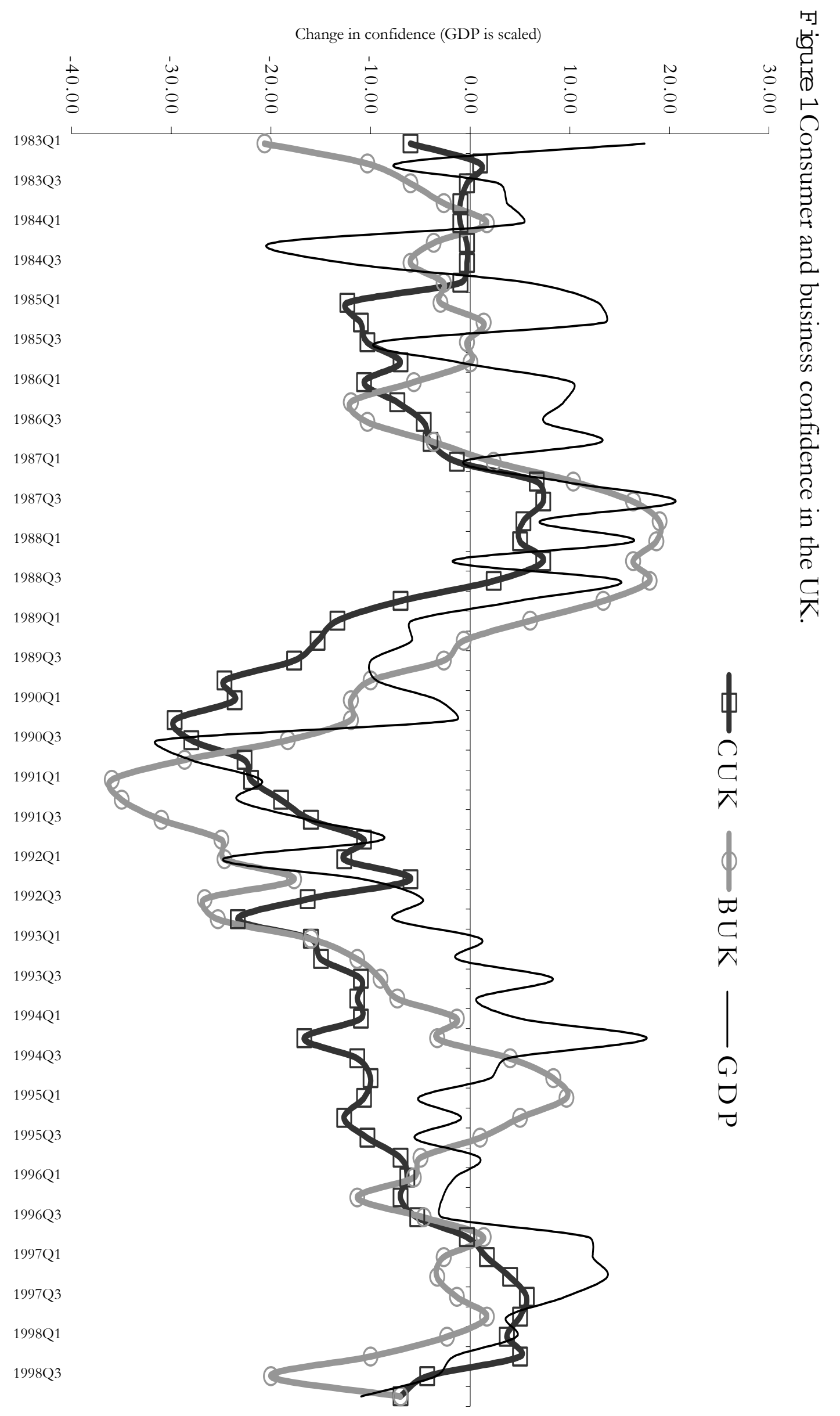




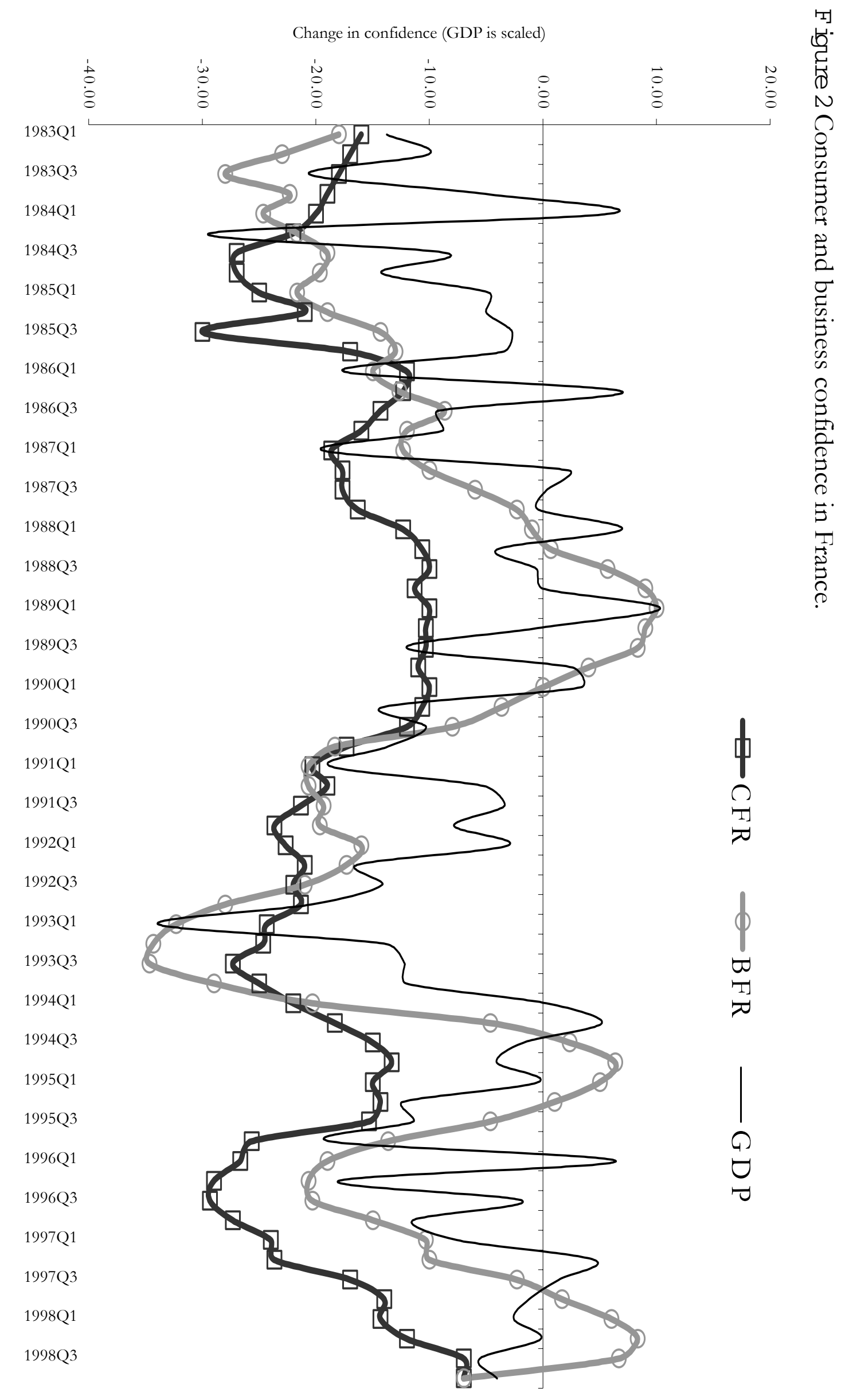




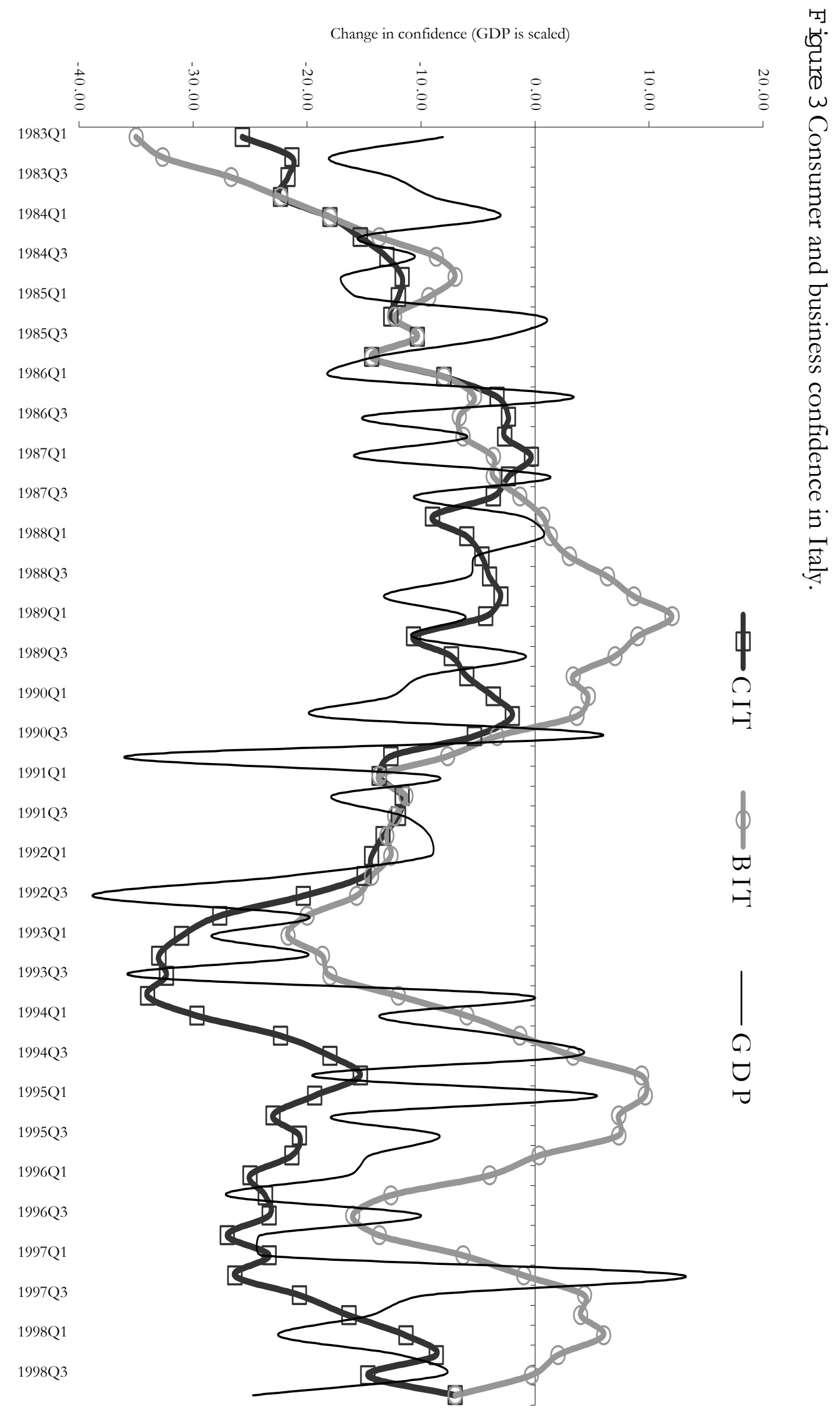




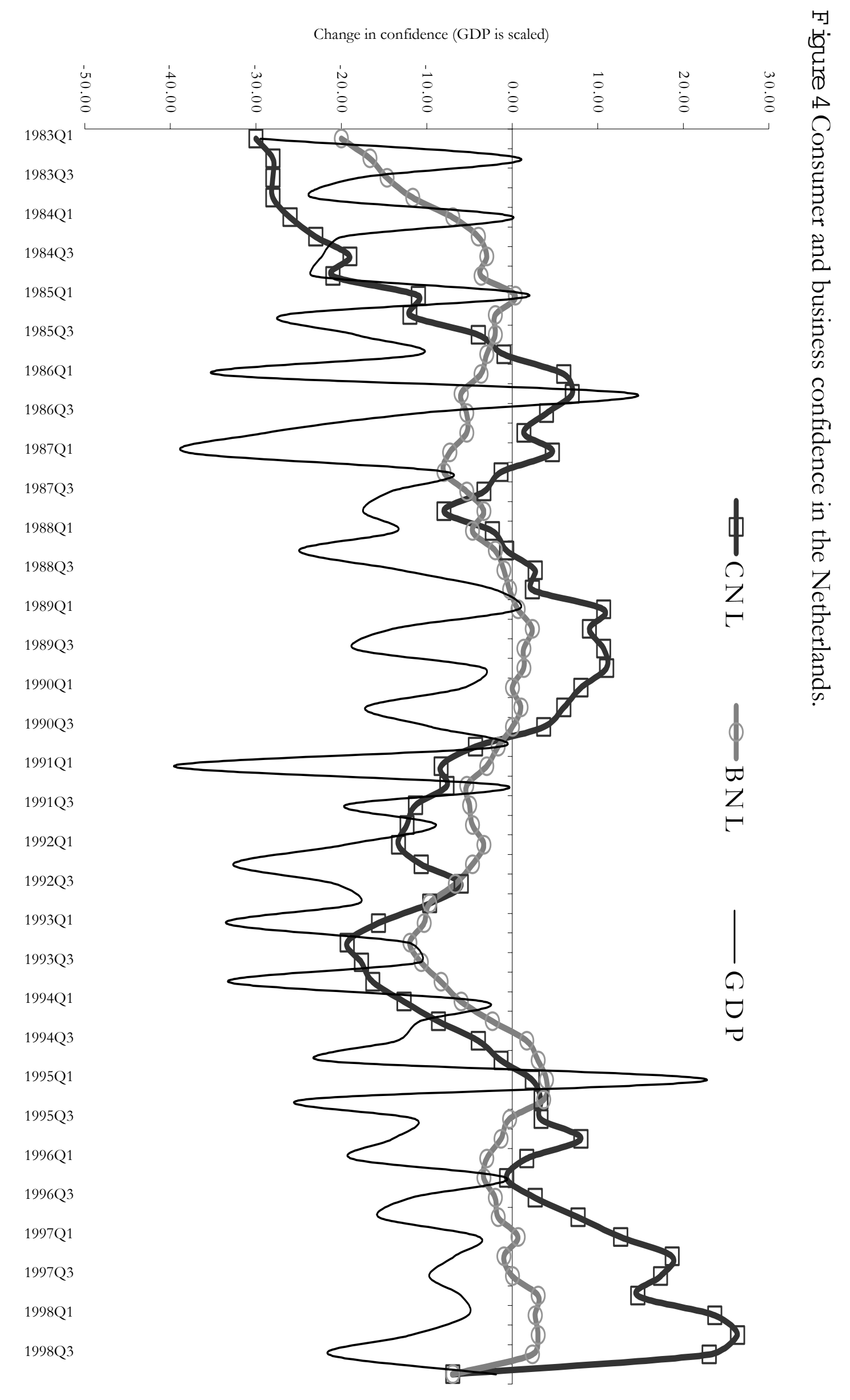


Table 1 UK Business Cycle Facts.

\begin{tabular}{lccccccccccc}
\hline & $\sigma^{2}$ & $t-4$ & $t-3$ & $t-2$ & $t-1$ & $T$ & $t+1$ & $t+2$ & $t+3$ & $t+4$ \\
\hline Real wage & 0.0094 & 0.1146 & 0.1350 & 0.1470 & 0.1592 & 0.1333 & 0.0911 & 0.0078 & -0.0469 & -0.0863 \\
Employment & 0.0116 & 0.8477 & 0.8634 & 0.8589 & 0.7972 & 0.6833 & 0.5353 & 0.3553 & 0.1592 & -0.0379 \\
Consumer expenditure & 0.0169 & 0.4939 & 0.6402 & 0.7682 & 0.8673 & 0.9188 & 0.8869 & 0.8055 & 0.6735 & 0.5190 \\
Government expenditure & 0.0076 & 0.1724 & 0.0885 & -0.0477 & -0.1455 & -0.2613 & -0.3279 & -0.3729 & -0.4084 & -0.4696 \\
Gross Fixed Investment & 0.0452 & 0.6519 & 0.7026 & 0.7319 & 0.7487 & 0.7453 & 0.6983 & 0.5866 & 0.4897 & 0.3901 \\
Money supply M4 & 0.0261 & 0.7915 & 0.6795 & 0.5507 & 0.4212 & 0.2880 & 0.1373 & -0.0124 & -0.1695 & -0.3294 \\
Money Supply M0 & 0.0105 & 0.7674 & 0.7803 & 0.7658 & 0.7331 & 0.6823 & 0.5535 & 0.3927 & 0.2043 & 0.0165 \\
Unemployment rate & 0.1316 & -0.7789 & -0.8257 & -0.8374 & -0.7985 & -0.6971 & -0.5571 & -0.3786 & -0.1806 & 0.0232 \\
Interest rate & 0.1535 & 0.6609 & 0.5939 & 0.4991 & 0.3733 & 0.2368 & 0.0512 & -0.1266 & -0.2796 & -0.4044 \\
Real effective exchange rate & 0.0467 & 0.1547 & 0.1752 & 0.2019 & 0.1800 & 0.0878 & 0.0006 & -0.0811 & -0.1707 & -0.2517 \\
Consumer confidence & 0.0249 & 0.4273 & 0.5138 & 0.5694 & 0.5901 & 0.5784 & 0.5646 & 0.5175 & 0.4441 & 0.3369 \\
Business confidence & 0.0373 & 0.8794 & 0.9138 & 0.9023 & 0.8413 & 0.7373 & 0.5887 & 0.4153 & 0.2344 & 0.0512 \\
\hline The fist column repots the & & & & & & & & & & &
\end{tabular}

The first column reports the standard deviation of the variable listed. The remaining columns show the correlation of the variable listed with GDP at lags and leads 1 through to 4 i.e. $(\mathrm{t}-1 \ldots . \mathrm{t}-4)$ and $(\mathrm{t}+1 \ldots . \mathrm{t}+4)$. All data are detrended using the Hodrick-Prescott filter.

Sample period 1983q1 to 1998q4. The 3 strongest correlations are shown in bold. 
Table 2 France Business Cycle Facts.

\begin{tabular}{lccccccccccc}
\hline & $\sigma^{2}$ & $t-4$ & $t-3$ & $t-2$ & $t-1$ & $t$ & $t+1$ & $t+2$ & $t+3$ & $t+4$ \\
\hline Real wage & 0.0054 & 0.4264 & 0.3571 & 0.3079 & 0.1836 & 0.0717 & -0.0812 & -0.1937 & -0.3146 & -0.3884 \\
Employment & 0.0173 & 0.6715 & 0.8181 & 0.8109 & 0.7530 & 0.6241 & 0.4762 & 0.3234 & 0.1929 & 0.0947 \\
Consumer expenditure & 0.0076 & 0.3268 & 0.4076 & 0.5694 & 0.6119 & 0.7057 & 0.5583 & 0.4419 & 0.3117 & 0.1688 \\
Government expenditure & 0.0085 & -0.2159 & -0.3579 & -0.3546 & -0.3311 & -0.2554 & -0.2515 & -0.1986 & -0.1431 & -0.0716 \\
Gross Fixed Investment & 0.0288 & 0.3473 & 0.5402 & 0.6922 & 0.8133 & 0.9058 & 0.8339 & 0.7086 & 0.5873 & 0.4686 \\
Money supply M3 & 0.0189 & 0.7026 & 0.7854 & 0.6687 & 0.4934 & 0.2927 & 0.1605 & -0.0382 & -0.1552 & -0.2455 \\
Money Supply M1 & 0.0352 & 0.1658 & 0.2743 & 0.2266 & 0.1936 & 0.0849 & 0.1455 & 0.0868 & 0.0763 & -0.0094 \\
Unemployment rate & 0.0514 & -0.5781 & -0.7594 & -0.8569 & -0.8518 & -0.7916 & -0.6931 & -0.5421 & -0.3842 & -0.2384 \\
Interest rate & 0.0519 & 0.5856 & 0.6888 & 0.7019 & 0.6219 & 0.4559 & 0.2816 & 0.0713 & -0.1302 & -0.3039 \\
Real effective exchange rate & 0.0181 & -0.3096 & -0.2339 & -0.1922 & -0.2278 & -0.2991 & -0.3806 & -0.4165 & -0.3463 & -0.2062 \\
Consumer confidence & 0.0162 & 0.4558 & 0.5452 & 0.5613 & 0.4917 & 0.3591 & 0.1879 & 0.0329 & -0.0951 & -0.1737 \\
Business confidence & 0.0274 & 0.6559 & 0.8194 & 0.9056 & 0.8994 & 0.8091 & 0.6484 & 0.4473 & 0.2613 & 0.0981 \\
\hline The fist column repots the & & & & & & & & & & &
\end{tabular}

The first column reports the standard deviation of the variable listed. The remaining columns show the correlation of the variable listed with GDP at lags and leads 1 through to 4 i.e. $(\mathrm{t}-1 \ldots . . \mathrm{t}-4)$ and $(\mathrm{t}+1 \ldots . \mathrm{t}+4)$. All data are detrended using the Hodrick-Prescott filter.

Sample period 1983q1 to 1998q4. The 3 strongest correlations are shown in bold. 
Table 3 Italy Business Cycle Facts.

\begin{tabular}{lcccccccccc}
\hline & $\sigma^{2}$ & $t-4$ & $t-3$ & $t-2$ & $t-1$ & $t$ & $t+1$ & $t+2$ & $t+3$ & $t+4$ \\
\hline Real wage & 0.0154 & -0.4442 & -0.4986 & -0.4695 & -0.4059 & -0.3336 & -0.2792 & -0.3208 & -0.3985 & -0.4643 \\
Employment & 0.0076 & 0.5662 & 0.6096 & 0.6214 & 0.5835 & 0.4875 & 0.3260 & 0.1529 & -0.0358 & -0.2419 \\
Consumer expenditure & 0.0099 & 0.3947 & 0.5117 & 0.6395 & 0.7352 & 0.7685 & 0.6942 & 0.5255 & 0.3162 & 0.0774 \\
Government expenditure & 0.0049 & -0.0443 & -0.0736 & -0.1004 & -0.0736 & -0.1038 & -0.1214 & -0.0584 & 0.0261 & 0.0957 \\
Gross Fixed Investment & 0.0349 & 0.5573 & 0.7118 & 0.8127 & 0.8551 & 0.8203 & 0.6466 & 0.4354 & 0.2075 & -0.0259 \\
Money Supply M1 & 0.0228 & -0.2764 & -0.2694 & -0.2636 & -0.2567 & -0.2228 & -0.0771 & -0.0142 & -0.0562 & -0.1288 \\
Unemployment rate & 0.0398 & -0.4763 & -0.3905 & -0.2073 & -0.0909 & 0.1137 & 0.2946 & 0.4768 & 0.4827 & 0.5103 \\
Interest rate & 0.1188 & 0.4786 & 0.6169 & 0.6222 & 0.5272 & 0.3855 & 0.1852 & -0.0188 & -0.1962 & -0.3359 \\
Real effective exchange rate & 0.0448 & 0.4798 & 0.3908 & 0.3859 & 0.3037 & 0.1951 & 0.1332 & 0.0382 & -0.0446 & -0.1129 \\
Consumer confidence & 0.0313 & 0.2712 & 0.3429 & 0.3432 & 0.2583 & 0.1514 & 0.0325 & -0.0965 & -0.1851 & -0.2694 \\
Business confidence & 0.0308 & 0.6014 & 0.7579 & 0.8470 & 0.8577 & 0.7800 & 0.6372 & 0.4661 & 0.2887 & 0.1221 \\
\hline The fist colnm & & & & & & & & & &
\end{tabular}

The first column reports the standard deviation of the variable listed. The remaining columns show the correlation of the variable listed with GDP at lags and leads 1 through to 4 i.e. $(\mathrm{t}-1 \ldots . . \mathrm{t}-4)$ and $(\mathrm{t}+1 \ldots . \mathrm{t}+4)$. All data are detrended using the Hodrick-Prescott filter.

Sample period $1983 \mathrm{q} 1$ to $1998 \mathrm{q} 4$. The 3 strongest correlations are shown in bold. 
Table 4 Netherlands Business Cycle Facts.

\begin{tabular}{lccccccccccc}
\hline & $\sigma^{2}$ & $t-4$ & $t-3$ & $t-2$ & $t-1$ & $t$ & $t+1$ & $t+2$ & $t+3$ & $t+4$ \\
\hline Real wage & 0.0108 & 0.1223 & -0.0369 & -0.0518 & -0.1765 & -0.2945 & -0.4347 & -0.5822 & -0.4529 & -0.3755 \\
Employment & 0.0484 & 0.0061 & 0.0877 & 0.2712 & 0.1975 & 0.1581 & 0.1374 & 0.0813 & 0.0960 & 0.0918 \\
Consumer expenditure & 0.0086 & 0.5319 & 0.5799 & 0.4689 & 0.4786 & 0.4942 & 0.2879 & 0.1595 & 0.0893 & -0.0733 \\
Government expenditure & 0.0093 & 0.1427 & 0.1381 & 0.1412 & 0.1765 & -0.0170 & 0.1809 & 0.1139 & -0.0493 & -0.0711 \\
Gross Fixed Investment & 0.0632 & -0.1779 & -0.2573 & -0.1891 & -0.1857 & 0.1462 & -0.1074 & -0.0415 & 0.0346 & 0.1797 \\
Money supply M3 & 0.0187 & 0.3458 & 0.2939 & 0.2614 & 0.2216 & 0.2446 & 0.1641 & 0.1359 & 0.0981 & 0.0640 \\
Money Supply M1 & 0.0272 & 0.2368 & 0.1793 & 0.0839 & -0.0613 & 0.0355 & -0.0358 & -0.0324 & 0.0148 & 0.1079 \\
Unemployment rate & 0.0894 & -0.6762 & -0.7012 & -0.6704 & -0.5908 & -0.5027 & -0.3756 & -0.2276 & -0.0780 & 0.0766 \\
Interest rate & 0.0872 & 0.3412 & 0.4277 & 0.5186 & 0.6288 & 0.5913 & 0.5619 & 0.5345 & 0.3802 & 0.2179 \\
Real effective exchange rate & 0.1015 & -0.1819 & -0.2169 & -0.2501 & -0.2359 & -0.3428 & -0.3598 & -0.3434 & -0.3124 & -0.2645 \\
Consumer confidence & 0.0347 & 0.4389 & 0.5254 & 0.5570 & 0.5294 & 0.4794 & 0.4763 & 0.4002 & 0.3093 & 0.2396 \\
Business confidence & 0.0109 & 0.5139 & 0.6475 & 0.7426 & 0.7619 & 0.6799 & 0.6416 & 0.5221 & 0.3761 & 0.2511 \\
\hline The first colmn res & & & & & & & & & & &
\end{tabular}

The first column reports the standard deviation of the variable listed. The remaining columns show the correlation of the variable listed with GDP at lags and leads 1 through to 4 i.e. $(\mathrm{t}-1 \ldots . \mathrm{t}-4)$ and $(\mathrm{t}+1 \ldots . \mathrm{t}+4)$. All data are detrended using the Hodrick-Prescott filter.

Sample period 1983q1 to 1998q4. The 3 strongest correlations are shown in bold. 
Table 5 Multivariate Business Cycle Facts.

\begin{tabular}{lcccc}
\hline & Coefficient & T - ratio & Coefficient & T - ratio \\
\hline Intercept & 0.00172 & 0.6899 & -1.08331 & -2.6400 \\
Real wage & 0.03417 & 0.6719 & 0.05555 & 1.0614 \\
Employment & -0.00515 & -0.3507 & -0.02493 & -1.7208 \\
Consumer expenditure & 0.77662 & 15.9494 & na & na \\
Government expenditure & 0.28076 & 6.7212 & 0.05192 & na \\
Gross Fixed Investment & 0.04098 & 3.5364 & -0.01516 & 5.3144 \\
Money Supply (narrow) & -0.01589 & -3.7243 & 0.00061 & -1.1337 \\
Unemployment rate & 0.01133 & 1.4363 & 0.00348 & 0.0452 \\
Interest rate & 0.00763 & 1.2177 & -0.01629 & 0.4810 \\
Real effective exchange rate & -0.05665 & -3.3650 & -0.14976 & -0.7619 \\
Consumer confidence & -0.00259 & -0.1408 & 0.13677 & -2.2199 \\
Business confidence & 0.09633 & 2.9999 & 2.5970
\end{tabular}

Observations

$\overline{\mathrm{R}}^{2}$
256

0.9989
0.9981

All data are detrended using the Hodrick-Prescott filter. Sample period 1983q1 to 1998q4. The 3 strongest correlations are shown in bold. Estimation is based upon Cochrane-Orcutt AR(4) method. Controls used in the regression are a time trend and country dummies (with the UK as the reference group). 
Table 6 Confidence Indicators Granger Non-Causality Tests.

ConfidenceG ranger couses $\mathrm{D} P$ P gce

G D P gcleG ranger causes Confidence

Consumer confidence Business confidence Consumer confidence Business confidence

\begin{tabular}{|c|c|c|c|c|}
\hline UK & $4.172 *$ & 0.372 & 3.542 & $5.295^{*}$ \\
\hline France & 0.101 & $5.483^{*}$ & 1.725 & 3.074 \\
\hline Italy & 0.022 & $4.328 *$ & 1.274 & 0.915 \\
\hline Netherlands & 0.270 & 0.784 & 0.185 & 3.209 \\
\hline
\end{tabular}

Each VAR has a lag length of 2 chosen by the Schwartz criterion and includes leading indicators identified from Tables 1 to 4.

The LR test statistic is based upon a Chi Squared and * denotes significance at the 5 per cent level or above. 
Table 7 Orthogonalised forecast error variance decompositions 8 quarters ahead for the UK.

\begin{tabular}{|c|c|c|c|c|c|c|c|c|c|c|}
\hline H orizon & GDP & $\begin{array}{l}\text { Business } \\
\text { confidence }\end{array}$ & $\begin{array}{l}\text { Consumer } \\
\text { confidence }\end{array}$ & Real wages & Employment & M4 & $\mathrm{MO}$ & Unemployment & $\begin{array}{l}\text { Interest } \\
\text { rate }\end{array}$ & $\begin{array}{c}\text { Exchange } \\
\text { rate }\end{array}$ \\
\hline 1 quarter & $88.6 \%$ & $0.0 \%$ & $8.6 \%$ & $0.2 \%$ & $0.0 \%$ & $0.0 \%$ & $1.0 \%$ & $0.2 \%$ & $1.1 \%$ & $0.2 \%$ \\
\hline 2 quarters & $73.8 \%$ & $0.7 \%$ & $18.3 \%$ & $3.0 \%$ & $1.2 \%$ & $0.1 \%$ & $0.1 \%$ & $0.1 \%$ & $1.3 \%$ & $1.3 \%$ \\
\hline 3 quarters & $64.3 \%$ & $0.9 \%$ & $20.2 \%$ & $4.6 \%$ & $3.9 \%$ & $0.1 \%$ & $1.2 \%$ & $0.2 \%$ & $2.2 \%$ & $2.4 \%$ \\
\hline 4 quarters & $58.9 \%$ & $0.6 \%$ & $19.9 \%$ & $5.6 \%$ & $6.3 \%$ & $0.4 \%$ & $2.4 \%$ & $0.6 \%$ & $2.3 \%$ & $3.0 \%$ \\
\hline 5 quarters & $56.9 \%$ & $1.4 \%$ & $19.1 \%$ & $5.7 \%$ & $7.2 \%$ & $0.5 \%$ & $3.3 \%$ & $0.7 \%$ & $2.3 \%$ & $2.9 \%$ \\
\hline 6 quarters & $53.9 \%$ & $3.6 \%$ & $17.7 \%$ & $5.1 \%$ & $8.7 \%$ & $0.7 \%$ & $3.9 \%$ & $0.8 \%$ & $2.5 \%$ & $3.0 \%$ \\
\hline 7 quarters & $52.1 \%$ & $5.0 \%$ & $16.5 \%$ & $4.8 \%$ & $9.6 \%$ & $1.1 \%$ & $3.8 \%$ & $1.1 \%$ & $2.7 \%$ & $3.2 \%$ \\
\hline 8 quarters & $49.9 \%$ & $5.4 \%$ & $15.6 \%$ & $4.5 \%$ & $9.6 \%$ & $2.1 \%$ & $3.7 \%$ & $1.7 \%$ & $3.5 \%$ & $3.9 \%$ \\
\hline
\end{tabular}

The underlying VAR has a lag length of 2 chosen by the Schwartz criterion. 
Table 8 Orthogonalised forecast error variance decompositions 8 quarters ahead for France.

\begin{tabular}{|c|c|c|c|c|c|c|c|c|c|c|}
\hline H orizon & GDP & $\begin{array}{l}\text { Business } \\
\text { confidence }\end{array}$ & $\begin{array}{l}\text { Consumer } \\
\text { confidence }\end{array}$ & Real wages & Employment & $\begin{array}{l}\text { Consumer } \\
\text { expenditure }\end{array}$ & $\begin{array}{l}\text { Government } \\
\text { expenditure }\end{array}$ & M3 & M1 & $\begin{array}{l}\text { Exchange } \\
\text { rate }\end{array}$ \\
\hline 1 quarter & $35.9 \%$ & $44.7 \%$ & $2.7 \%$ & $8.3 \%$ & $2.3 \%$ & $0.0 \%$ & $2.4 \%$ & $1.8 \%$ & $0.0 \%$ & $1.8 \%$ \\
\hline 2 quarters & $25.1 \%$ & $50.4 \%$ & $3.9 \%$ & $11.5 \%$ & $2.5 \%$ & $0.1 \%$ & $1.5 \%$ & $2.0 \%$ & $0.4 \%$ & $1.6 \%$ \\
\hline 3 quarters & $17.3 \%$ & $45.4 \%$ & $9.8 \%$ & $16.9 \%$ & $2.1 \%$ & $1.6 \%$ & $2.3 \%$ & $2.7 \%$ & $0.3 \%$ & $1.5 \%$ \\
\hline 4 quarters & $13.6 \%$ & $39.2 \%$ & $13.9 \%$ & $21.6 \%$ & $1.6 \%$ & $1.3 \%$ & $2.8 \%$ & $4.2 \%$ & $0.3 \%$ & $1.5 \%$ \\
\hline 6 quarters & $9.2 \%$ & $27.7 \%$ & $15.6 \%$ & $29.2 \%$ & $1.7 \%$ & $0.9 \%$ & $3.1 \%$ & $9.6 \%$ & $1.3 \%$ & $1.7 \%$ \\
\hline 7 quarters & $7.8 \%$ & $27.6 \%$ & $13.9 \%$ & $29.3 \%$ & $1.5 \%$ & $1.6 \%$ & $2.6 \%$ & $11.9 \%$ & $2.2 \%$ & $1.5 \%$ \\
\hline 8 quarters & $6.9 \%$ & $27.7 \%$ & $12.5 \%$ & $29.2 \%$ & $1.6 \%$ & $1.9 \%$ & $2.5 \%$ & $13.5 \%$ & $3.0 \%$ & $1.3 \%$ \\
\hline
\end{tabular}

The underlying VAR has a lag length of 2 chosen by the Schwartz criterion. 
Table 9 Orthogonalised forecast error variance decompositions 8 quarters ahead for Italy.

\begin{tabular}{|c|c|c|c|c|c|c|c|c|c|c|c|}
\hline H orizon & GDP & $\begin{array}{c}\text { Business } \\
\text { confidence }\end{array}$ & $\begin{array}{l}\text { Consumer } \\
\text { confidence }\end{array}$ & $\begin{array}{c}\text { Real } \\
\text { wages }\end{array}$ & Employment & $\begin{array}{l}\text { Consumer } \\
\text { expenditure }\end{array}$ & $\begin{array}{l}\text { Government } \\
\text { expenditure }\end{array}$ & $\begin{array}{l}\text { Gross } \\
\text { fixed } \\
\text { invest }\end{array}$ & M1 & $\begin{array}{l}\text { Interest } \\
\text { rate }\end{array}$ & $\begin{array}{c}\text { Exchange } \\
\text { rate }\end{array}$ \\
\hline 1 quarter & $75.1 \%$ & $2.9 \%$ & $0.1 \%$ & $6.5 \%$ & $0.3 \%$ & $1.8 \%$ & $5.8 \%$ & $0.2 \%$ & $0.5 \%$ & $6.7 \%$ & $0.0 \%$ \\
\hline 2 quarters & $50.4 \%$ & $17.9 \%$ & $8.9 \%$ & $6.5 \%$ & $0.3 \%$ & $2.1 \%$ & $4.2 \%$ & $0.3 \%$ & $2.4 \%$ & $6.9 \%$ & $0.0 \%$ \\
\hline 3 quarters & $32.9 \%$ & $12.8 \%$ & $23.3 \%$ & $5.2 \%$ & $1.9 \%$ & $9.2 \%$ & $2.7 \%$ & $5.6 \%$ & $1.7 \%$ & $4.5 \%$ & $0.2 \%$ \\
\hline 4 quarters & $29.2 \%$ & $9.6 \%$ & $17.2 \%$ & $5.4 \%$ & $5.7 \%$ & $9.9 \%$ & $5.6 \%$ & $9.9 \%$ & $1.7 \%$ & $5.0 \%$ & $0.7 \%$ \\
\hline 5 quarters & $27.9 \%$ & $9.7 \%$ & $19.9 \%$ & $5.7 \%$ & $5.2 \%$ & $7.5 \%$ & $4.4 \%$ & $10.9 \%$ & $3.6 \%$ & $4.5 \%$ & $0.7 \%$ \\
\hline 6 quarters & $21.5 \%$ & $16.0 \%$ & $20.3 \%$ & $7.5 \%$ & $4.8 \%$ & $5.9 \%$ & $3.3 \%$ & $8.5 \%$ & $6.9 \%$ & $4.8 \%$ & $0.5 \%$ \\
\hline 7 quarters & $19.0 \%$ & $15.4 \%$ & $22.1 \%$ & $6.9 \%$ & $4.7 \%$ & $6.6 \%$ & $5.6 \%$ & $7.8 \%$ & $6.0 \%$ & $4.8 \%$ & $1.1 \%$ \\
\hline 8 quarters & $18.1 \%$ & $14.5 \%$ & $18.9 \%$ & $13.5 \%$ & $6.8 \%$ & $6.7 \%$ & $4.7 \%$ & $6.5 \%$ & $4.9 \%$ & $3.9 \%$ & $1.4 \%$ \\
\hline
\end{tabular}

The underlying VAR has a lag length of 2 chosen by the Schwartz criterion. 
Table 10 Orthogonalised forecast error variance decompositions 8 quarters ahead for the Netherlands.

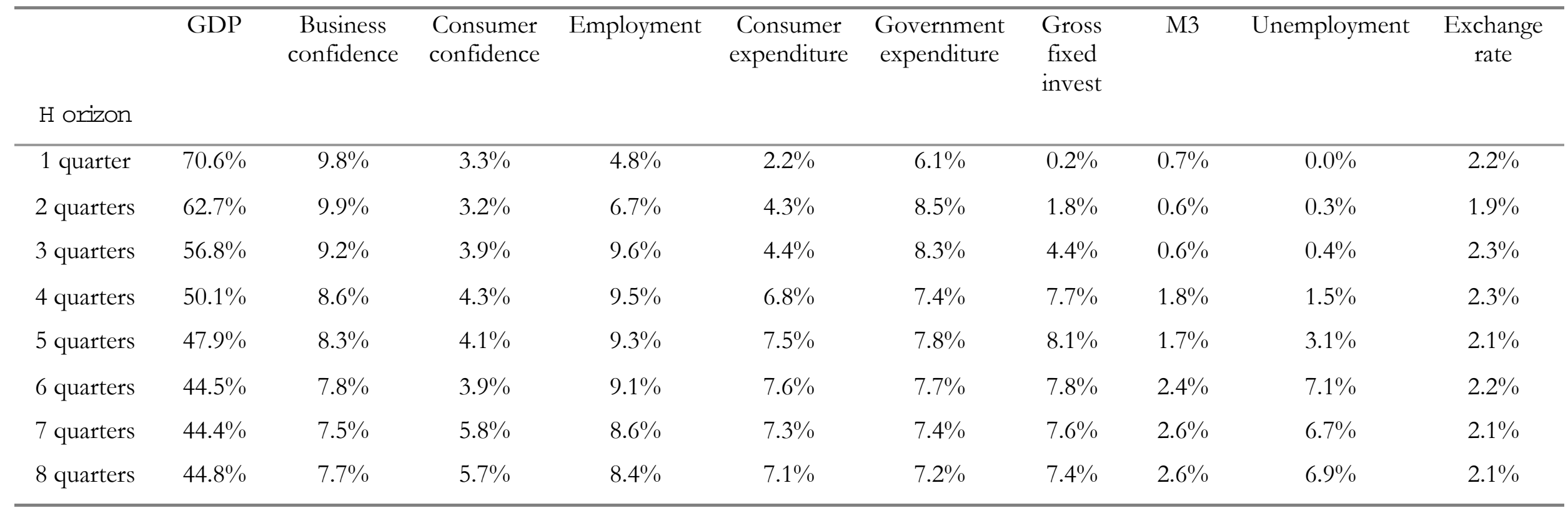

The underlying VAR has a lag length of 2 chosen by the Schwartz criterion. 
Table $11 \mathrm{UK}$ measures of fit and $\mathrm{t}$-statistics for probit model $\mathrm{k}$ quarters ahead.

\begin{tabular}{|c|c|c|c|c|c|c|c|c|c|}
\hline & $\begin{array}{c}\text { Business } \\
\text { confidence }\end{array}$ & $\begin{array}{l}\text { Consumer } \\
\text { confidence }\end{array}$ & Real wages & Employment & M4 & $\mathrm{MO}$ & Unemployment & Interest rate & $\begin{array}{c}\text { Exchange } \\
\text { rate }\end{array}$ \\
\hline \multicolumn{10}{|l|}{$\mathrm{k}=1$ period } \\
\hline PsadoR ${ }^{2}$ & & & & & 0387 & & & & \\
\hline t-stat & $-20374(1)$ & $-12.071(4)$ & $-7.647(3)$ & $11.164(2)$ & 10.879 & 2.184 & 15293 & 115.628 & -3.085 \\
\hline \multicolumn{10}{|l|}{$\mathrm{k}=2$ periods } \\
\hline $\mathrm{Pseda} \mathrm{R}^{2}$ & & & & & 0317 & & & & \\
\hline t-stat & $-6.356(3)$ & $-9.524(4)$ & -3.410 & $6229(1)$ & 2.582 & $-4.438(2)$ & 7.625 & 18.117 & 1.427 \\
\hline \multicolumn{10}{|l|}{$\mathrm{k}=3$ periods } \\
\hline Psatob $R^{2}$ & & & & & 0302 & & & & \\
\hline t-stat & $-4.424(4)$ & $-12.176(3)$ & 1.219 & $6.928(1)$ & -0.347 & $-10.445(2)$ & 2.942 & 10.069 & 1.990 \\
\hline \multicolumn{10}{|l|}{$\mathrm{k}=4$ periods } \\
\hline Psado $R^{2}$ & & & & & 0313 & & & & \\
\hline t-stat & $-5.489(4)$ & $-9.980(3)$ & 1.205 & $4.441(1)$ & -0.434 & $-6.328(2)$ & 1.557 & 9.462 & 3.322 \\
\hline
\end{tabular}

(.) shows the rank of the largest 4 coefficients in absolute terms. 
Table 12 France measures of fit and t-statistics for probit model $\mathrm{k}$ quarters ahead.

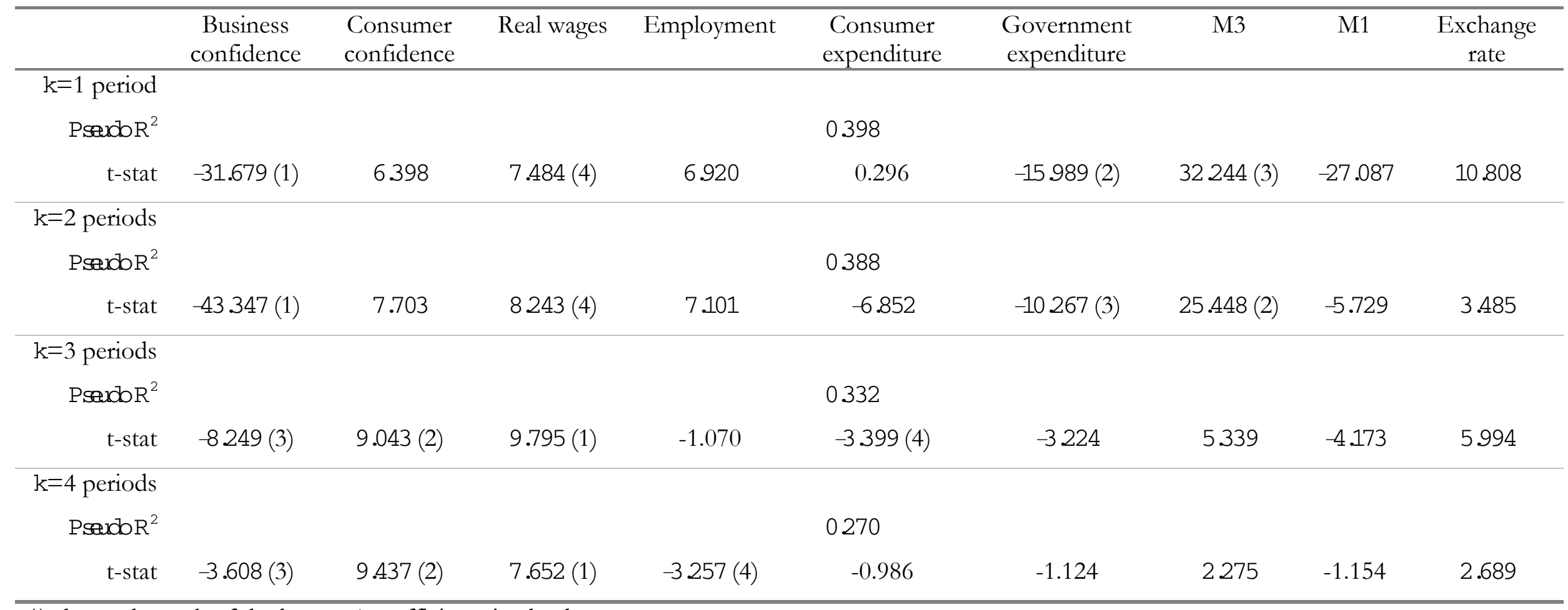

(.) shows the rank of the largest 4 coefficients in absolute terms. 
Table 13 Italy measures of fit and t-statistics for probit model $\mathrm{k}$ quarters ahead.

\begin{tabular}{|c|c|c|c|c|c|c|c|c|c|c|}
\hline & $\begin{array}{c}\text { Business } \\
\text { confidence }\end{array}$ & $\begin{array}{l}\text { Consumer } \\
\text { confidence }\end{array}$ & $\begin{array}{c}\text { Real } \\
\text { wages }\end{array}$ & Employment & $\begin{array}{l}\text { Consumer } \\
\text { expenditure }\end{array}$ & $\begin{array}{l}\text { Government } \\
\text { expenditure }\end{array}$ & $\begin{array}{l}\text { Gross fixed } \\
\text { investment }\end{array}$ & M1 & $\begin{array}{l}\text { Interest } \\
\text { rates }\end{array}$ & $\begin{array}{c}\text { Exchange } \\
\text { rate }\end{array}$ \\
\hline \multicolumn{11}{|l|}{$\mathrm{K}=1$ period } \\
\hline Psacob $R^{2}$ & & & & & 0.393 & & & & & \\
\hline t-stat & -4.317 & 2283 & 6.378 & 22206 (1) & $-23.617(2)$ & $-4.585(3)$ & -6.014 & $-10.188(4)$ & -1.518 & 15.777 \\
\hline \multicolumn{11}{|l|}{$\mathrm{k}=2$ periods } \\
\hline$P \operatorname{sen} 0 R^{2}$ & & & & & 0364 & & & & & \\
\hline t-stat & -0.045 & 4.832 & $5331(4)$ & $3.384(3)$ & $-13.774(1)$ & $-11295(2)$ & -0.509 & 9.601 & 4.145 & 8.852 \\
\hline \multicolumn{11}{|l|}{$\mathrm{k}=3$ periods } \\
\hline$P \sec 0 R^{2}$ & & & & & 0395 & & & & & \\
\hline t-stat & 1.064 & 0.561 & 22359 (4) & $20.622(3)$ & $-21.458(2)$ & $-14245(1)$ & -4.077 & 11.498 & 14.564 & 4.443 \\
\hline \multicolumn{11}{|l|}{$\mathrm{k}=4$ periods } \\
\hline PsadoR ${ }^{2}$ & & & & & 0399 & & & & & \\
\hline t-stat & -2.767 & -0.128 & $31.867(4)$ & $38391(1)$ & $-49.312(3)$ & $-34.188(2)$ & -9.022 & 1.623 & 12.097 & -15209 \\
\hline
\end{tabular}

(.) shows the rank of the largest 4 coefficients in absolute terms. 
Table 14 Netherlands measures of fit and t-statistics for probit model k quarters ahead.

\begin{tabular}{|c|c|c|c|c|c|c|c|c|c|}
\hline & $\begin{array}{l}\text { Business } \\
\text { confidence }\end{array}$ & $\begin{array}{l}\text { Consumer } \\
\text { confidence }\end{array}$ & Employment & $\begin{array}{l}\text { Consumer } \\
\text { expenditure }\end{array}$ & $\begin{array}{l}\text { Government } \\
\text { expenditure }\end{array}$ & $\begin{array}{l}\text { Gross fixed } \\
\text { investment }\end{array}$ & M3 & Unemployment & $\begin{array}{l}\text { Interest } \\
\text { rate }\end{array}$ \\
\hline$P \operatorname{sendo} R^{2}$ & & & & & 0267 & & & & \\
\hline t-stat & $-6228(1)$ & $-3.804(3)$ & 0.758 & 1.042 & $2.772(2)$ & -1.305 & -1.785 & $-5.688(4)$ & -0.554 \\
\hline \multicolumn{10}{|l|}{$\mathrm{k}=2$ periods } \\
\hline Psando $R^{2}$ & & & & & 0217 & & & & \\
\hline \multicolumn{10}{|l|}{$\mathrm{k}=3$ periods } \\
\hline PsatoR $R^{2}$ & & & & & 0229 & & & & \\
\hline t-stat & $-4.390(1)$ & -2.878 & 1.521 & $5.103(2)$ & $2245(3)$ & -0.991 & $-3.808(4)$ & 2.360 & 0.910 \\
\hline \multicolumn{10}{|l|}{$\mathrm{k}=4$ periods } \\
\hline
\end{tabular}

(.) shows the rank of the largest 4 coefficients in absolute terms. 